\title{
Use of the BMWP and ASPT indexes for monitoring environmental quality in a neotropical stream
}

\author{
Uso dos índices BMWP e ASPT no monitoramento
}

da qualidade ambiental em um riacho neotropical

\author{
Kennedy Francis Roche ${ }^{1}$, Ednilson Paulino Queiroz ${ }^{2}$, \\ Karina Ocampo Righi ${ }^{3}$ and Gláucio Mendes de Souza ${ }^{2}$
}

${ }^{1}$ Departamento de Hidráulica e Transportes, Universidade Federal de Mato Grosso do Sul - UFMS, Cidade Universitária, CP 549, CEP 79070-900, Campo Grande, MS, Brazil e-mail: kroche@nin.ufms.br

${ }^{2}$ Polícia Militar Ambiental - MS, Av. Mato Grosso s/n, Parque das Naçóes Indígenas, CEP 79031-00, Campo Grande, MS, Brazil e-mail: ednilson_queiroz@yahoo.com.br; gmendesdesouza@yahoo.com.br

${ }^{3}$ Programa de Pós-graduação em Entomologia, Laboratório de Entomologia Aquática, Faculdade de Filosofia, Ciências e Letras de Ribeirão Preto - FFCLRP - Departamento de Biologia, Universidade de São Paulo, Av. dos Bandeirantes, 3900, CEP 14040-901, Ribeirão Preto, SP, Brazil e-mail: karina.righi@gmail.com

\begin{abstract}
The aim of the present study was to examine the applicability of versions of the Biological Monitoring Working Party index, the original from Great Britain (Armitage et al., 1983), and adaptations from Spain (Alba-Tercedor and Sánchez-Ortega, 1988) and Brazil (Junqueira and Campos, 1998; Junqueira et al., 2000; Monteiro et al., 2008), and the associated Average Score Per Taxon, in evaluating the environmental quality of a stream in the center-west of Brazil. In the wet and dry seasons, the stream was sampled at three sites, reflecting a gradient of increasing levels of anthropogenic impact from sites 1 to 3 , and the different index values calculated. The adaptations by Junqueira et al. (2000) and Monteiro et al. (2008) presented the highest values. The values of the versions of Junqueira and Campos (1998) and Junqueira et al. (2000) generally decreased from sites 1 to 3 on both dates. Decreases in environmental quality on the wet season sampling date were indicated by the BMWP scores more so than by the ASPT scores. The adaptations by Junqueira and Campos (1998) and especially Junqueira et al. (2000) seem to have detected, with the greatest degree of sensitivity, the putative decrease in environmental quality from sites 1 to 3 . The use of the ASPT seemed to diminish the possible impact of natural seasonal differences in organism abundances on the indicated degree of pollution.
\end{abstract}

Keywords: macroinvertebrates, biomonitoring, indexes.

Resumo: $\mathrm{O}$ objetivo do presente estudo foi de examinar a aplicabilidade de versóes do Índice Biological Monitoring Working Party, o original da Grã-Bretanha (Armitage et al., 1983), e as adaptaçôes da Espanha (Alba-Tercedor e Sánchez-Ortega, 1988) e do Brasil (Junqueira e Campos, 1998; Junqueira et al., 2000; Monteiro et al., 2008), e o associado Average Score Per Taxon, na avaliação da qualidade ambiental de um riacho no centro-oeste do Brasil. Nas épocas chuvosas e secas, o riacho foi amostrado em três pontos, refletindo um gradiente de impacto antrópico, e as diferentes versôes do índice calculadas. As adaptações feitas por Junqueira et al. (2000) e Monteiro et al. (2008) apresentaram os maiores valores. Os valores das versóes de Junqueira e Campos (1998) e Junqueira et al. (2000) geralmente diminuíram dos pontos 1 a $3 \mathrm{em}$ ambas as datas de amostragem. Diminuições em qualidade ambiental na época chuvosa foram indicadas mais pelo BMWP do que pelo ASPT. As adaptaçóes feitas por Junqueira e Campos (1998) e especialmente Junqueira et al. (2000) aparentemente detectaram, com um maior grau de sensibilidade a suposta diminuiçáo da qualidade ambiental dos pontos 1 a 3 . O uso do ASPT pareceu diminuir o impacto possível das diferenças naturais sazonais em abundâncias dos organismos no grau de poluição indicado.

Palavras-chave: macroinvertebrados, biomonitoramento, índices. 
The use of macroinvertebrate indices for monitoring stream environmental quality is well established; a much used index is that of the Biological Monitoring Working Party (BMWP) from Great Britain (Armitage et al., 1983). This index may require adaptation for use in other regions, principally because the macroinvertebrate families involved may be absent from the region under consideration, being replaced by different taxa; also, families may exhibit different pollution tolerances from region to region (Buss and Salles, 2006). When choosing an index adaptation to use, it might seem logical to select a version developed in a region with the greatest degree of geographical proximity. However, if such an adaptation were based on a less rigorous analysis using fewer data than that of the original version, or its region of origin presented marked geological differences as compared to the region of application, the original might still perform better (Silveira et al., 2005).

The present study had the aim of examining the applicability of the original BMWP and associated Average Score Per Taxon (ASPT) (the total index score divided by the number of taxa encountered), and adaptations, one made in Spain (Alba-Tercedor and Sánchez-Ortega, 1988), and the others in the Brazilian states of Minas Gerais (Junqueira and Campos, 1998; Junqueira et al., 2000) and Goias (Monteiro et al., 2008), in reflecting the environmental quality at different sites, representing a gradient of increasing levels of anthropogenic impact, in the wet and dry seasons, of a neotropical stream. The two versions from Minas Gerais were compared, because, although the more recent adaptation (Junqueira et al., 2000) was intended to replace the older version (Junqueira and Campos, 1998), the latter still continues to be used (Silveira et al., 2005).

The studied stream (Córrego Salto) $\left(20^{\circ} 10^{\prime} 30^{\prime \prime} \mathrm{S}\right.$ and $\left.54^{\circ} 34^{\prime} 40^{\prime \prime} \mathrm{W}\right)$ is situated in the center-west of Brazil. Three sampling sites were chosen. Site one, considered unimpacted, is located within an area of natural woodland, with riparian vegetation well conserved. Sites two and three are located within areas of agricultural activity (cattle grazing and crop cultivation). At site two, the riparian vegetation showed some evidence of degradation, with bank erosion. More fine sediment was present than at site one. At site three, riparian vegetation was even less developed, with significant signs of erosion and accumulation of fine sediment. Sampling was carried out on two dates, one at the end of the dry season (14 October/03), and one in the wet (10 February/04), using a $250 \mu \mathrm{m}$ mesh size Surber sampler.

The increase in the values for the versions of the BMWP (from Great Britain, through Spain, to Brazil), found at all sampling sites, on both dates (Figure 1), may be principally explained by the increasing degree of faunal similarity between these regions and that of the present study. Of the taxa found in the present study, only 1 to 2 are not present in the Brazilian versions, while 8 and 5 are not present in the Great British and Spanish versions, respectively. Another factor leading to the greater recorded values for the Brazilian versions was the differences in taxon tolerance scores
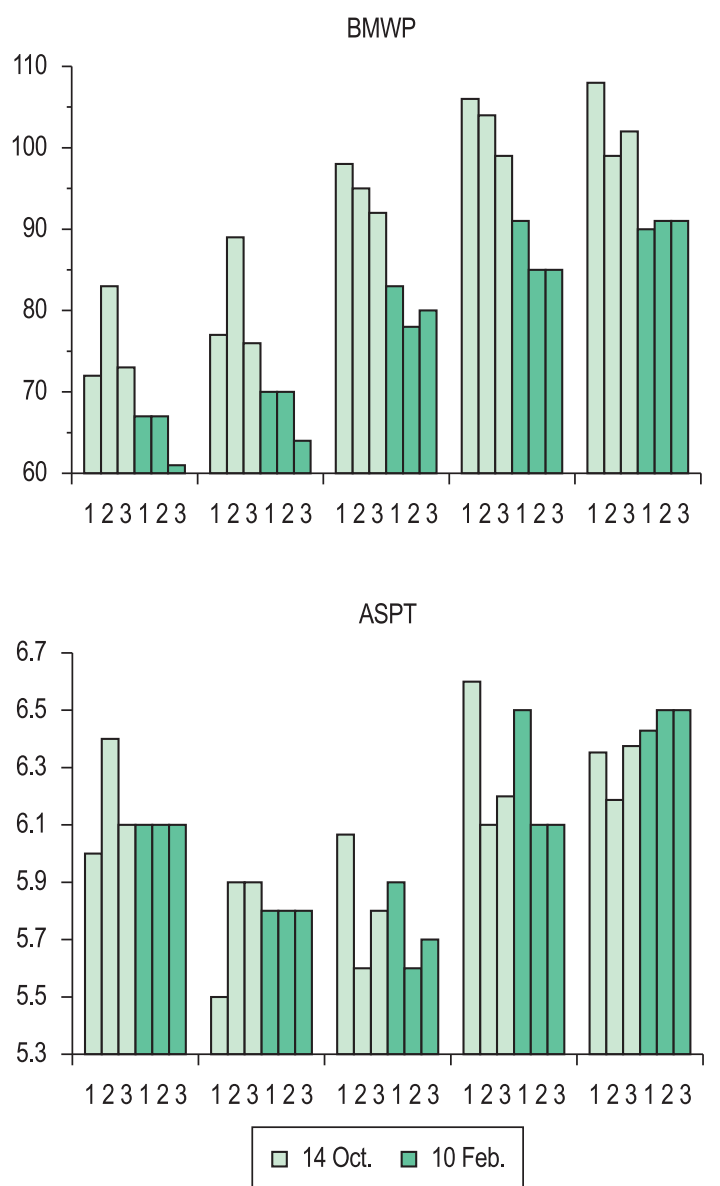

Figure 1. Values for the different versions (from left to right, Armitage et al. (1983), Alba-Tercedor and Sánchez-Ortega (1988), Junqueira and Campos (1998), Junqueira et al. (2000) and Monteiro et al. (2008) of the BMWP and ASPT indexes for each sampling site (1-3) and sampling date. 
allocated by the different versions. This was also the reason why the version of Junqueira and Campos (1998) presented lower values than the version of Junqueira et al. (2000).

Greater fidelity was shown by the Junqueira and Campos (1998) and especially the Junqueira et al. (2000) adaptations in reflecting the varying degrees of environmental degradation; i.e. for these versions, values of both the BMWP index and ASPT indicated a gradient in quality, on both dates, decreasing from sites one to two and three.

For the versions of Junqueira and Campos (1998) and Junqueira et al. (2000), BMWP values of approximately $>80-85,60-80,40-60$, $20-40$ and $<20$ indicate, respectively, excellent, good, average (satisfactory), bad and very bad water quality, while the equivalent values for the version of Monteiro et al. (2008) are $>149,100-149,60-99,20-59$ and $<20$. Thus, according to the former two versions, quality would have been consistently excellent on the first date and excellent to bordering on good on the second, while the latter version indicated good to bordering on average on the first date and average on the second date. Considering the pristine nature of site one and the visual signs of human impact at sites two and three, the former two versions might have somewhat overestimated environmental quality, while the opposite would have been the case for the latter version. However, the value of 80-85 used in the former versions as the cut-off between classifying waters as good or excellent could be considered as too low; Cota et al. (2002), using a slight modification of the former versions, recorded values of up to 209 in pristine low order streams in an adjacent region.

In field studies, the number of taxa found generally increases with the number of individuals sampled. In tropical streams, macroinvertebrate abundances tend to be lower in the wet season, than in the dry (Bispo et al., 2006). For the same degree of sampling effort, this scenario could lead to a decrease in the value of the BMWP index in the wet season, thereby suggesting, erroneously, an increase in pollution levels. In the present study, the lower BMWP values recorded for the wet season sampling date could be related to the lower abundance of organisms recorded on this date $(254,289$ and 360 individuals at sites one, two and three, respectively) as compared to the dry season date (763, 978 and 689 individuals at sites one, two and three, respectively). However, the ASPT values were not consistently lower on the wet season date as compared to the dry (Figure 1), supporting the suggestion that the lower BMWP values on the wet season date were not due to increased levels of pollution.

In conclusion, the version of Junqueira et al. (2000), modified by incorporating a higher value for the cut-off between good and excellent classifications, might here be the most appropriate of the versions tested. In addition, when comparing environmental quality between dry and wet seasons, use of the ASPT could be advantageous.

\section{References}

ALBA-TERCEDOR, J. and SÁNCHEZ-ORTEGA, A., 1988. Um método rápido y simple para evaluar la calidade biológica de las aguas corrientes basado em el de Hellawell (1978). Limnética, vol. 4, p. 51-56.

ARMiTAGE, PD., MOSS, D., WRIGHT, JF. and FURSE, MT., 1983. The performance of a new biological water quality score system based on macroinvertebrates over a wide range of unpolluted running-water sites. Water Research, vol. 17, no. 3, p. 333-347.

BISPO, PC., OLIVEIRA, LG., BINI, LM. and SOUZA, KG., 2006. Ephemeroptera, Plecoptera and Trichoptera assemblages from riffles in mountain streams of Central Brazil, Environmental factors influencing the distribution and abundance of immatures. Brazilian Journal of Biology, vol. 66, no. 2B, p. 611-622.

BUSS DF. and SALLES FF, 2006. Using Baetidae species as biological indicators of environmental degradation in a Brazilian river basin. Environmental Monitoring \& Assessment, vol. 130, no. 1-3, p. 365-372.

COTA, L., GOUlarT, M., MORENO, P. and CALLISTO, M., 2002. Rapid assessment of river quality using an adapted BMWP index: a practical tool to evaluate ecosystem health. Verhandlungen der Internationale Vereinigung fur Limnologie, vol. 28, no. 4, p. 1713-1716.

JUNQUEIRA, MV. and CAMPOS, SCM., 1998. Adaptation of the "BMWP" method for water quality evaluation to Rio das Velhas watershed (Minas Gerais, Brazil). Acta Limnologica Brasiliensia, vol. 10, no. 2, p. 125-135.

JUNQUEIRA, MV., AMARANTE, MC., DIAS, CFS. and FRANÇA, ES., 2000. Biomonitoramento da qualidade das águas da Bacia do Alto Rio das Velhas 
(MG/Brazil) através de macroinvertebrados. Acta Limnologica Brasiliensia, vol. 12, no. 1, p. 73-87.

MONTEIRO, TR., OLIVEIRA, LG. and SPACEK GODOY, BS., 2008. Biomonitoramento da qualidade de água utilizando macroinvertebrados bentônicos: adaptação do índice biótico BMWP' à bacia do rio Meia Ponte-GO. Oecologia Brasiliensis, vol 12, no. 3, p. 553-563.
SILVEIRA, MP., BAPTISTA, DF., BUSS, DF., NESSIMIAN, JL. and EGLER, M., 2005. Application of biological measures for stream integrity assessment in south-east Brazil. Environmental Monitoring \& Assessment, vol. 101, no. 1-3, p. 117-128.

Received: 01 September 2009 Accepted: 02 June 2010 